\title{
Indigenous health: New Zealand experience
}

What can the Treaty of Waitangi teach Australia about reducing disparities in health?

\begin{tabular}{|c|c|}
\hline $\begin{array}{r}\text { Mason } \\
\text { CNZM, } \\
\text { DPsyc } \\
\text { Professor of Maori } \\
\text { and Developm } \\
\text { Assistant Vice-Ch } \\
\text { (Maori \& }\end{array}$ & $\begin{array}{l}\text { he health status of indigenous populations in Aus- } \\
\text { tralia and New Zealand gives justified cause for } \\
\text { concern. After European colonisation, their survival } \\
\text { was threatened by a range of infectious diseases to which } \\
\text { they had little or no immunity. Though no longer the threat } \\
\text { posed in the 19th century, the incidence of infectious } \\
\text { diseases remains disproportionately high in indigenous } \\
\text { populations, }{ }^{1} \text { and a range of non-communicable chronic } \\
\text { diseases has also emerged, including cancers (breast, lung, } \\
\text { stomach), mental disorders, youth suicide, alcohol- and } \\
\text { drug-related disorders, obesity, obstructive respiratory dis- } \\
\text { ease, ischaemic heart disease, stroke and diabetes. }{ }^{2} \text { In both } \\
\text { Australia and New Zealand, the incidence of all these } \\
\text { conditions is significantly higher in the indigenous popula- } \\
\text { tion than the non-indigenous population. }{ }^{3} \\
\text { Solutions for indigenous health will depend on a range } \\
\text { of factors, most well outside clinical arenas. Consequently, } \\
\text { significant gains in health will be unlikely unless there is a } \\
\text { concerted intersectoral, whole-of-government approach } \\
\text { reflected in practices, legislation and national policies. }{ }^{4} \text { In } \\
\text { New Zealand, that prescription was signalled in the } 1840\end{array}$ \\
\hline
\end{tabular}

Treaty of Waitangi, when Maori and the Crown agreed to recognise British sovereignty in exchange for guarantees that indigenous rights to customary resources would be protected and that Maori would have the same "rights and privileges" as other British subjects. Although subsequent governments reneged on many Treaty promises, the Treaty of Waitangi Act 1975 endorsed the relevance of the Treaty to contemporary New Zealand and created a mechanism for dealing with claims against the Crown for breaches of the principles of the Treaty. Most such claims have concerned land, but the 1988 report of the Royal Commission on Social Policy affirmed that the principles of the Treaty, such as partnership, protection and participation, were also relevant to social policies including health and education. ${ }^{5}$ Later, under the New Zealand Public Health and Disability Act 2000, district health boards were required to "recognise and respect" the principles of the Treaty of Waitangi by ensuring Maori participation in decision making and in the delivery of health services.

A more recent and global statement on indigenous rights is contained in the United Nations declaration on the 
rights of indigenous peoples, to which Australia and New Zealand are now signatories. ${ }^{6}$ The Declaration is an aspirational document; although not binding on governments or able to override domestic law, it endorses the territorial, social, economic and cultural rights of indigenous peoples. Where treaties with indigenous peoples do not exist, as in Australia, the Declaration provides governments with an internationally recognised set of expectations for indigenous peoples.

Since 1984, a range of Maori health initiatives have been introduced, largely inspired by government commitments to the Treaty of Waitangi but also by increasing concern about health disparities between various population groups. Although disparities between Maori and nonMaori people have not decreased across all measures, there is recent evidence of an increase in Maori life expectancy, ${ }^{7}$ reductions in mortality rates, ${ }^{8}$ lower rates of suicide in older people, increased access to primary health care $^{2}$ and significant increases in smoking cessation for young Maori women. ${ }^{9}$ But of equal, if not greater, significance has been a change in Maori attitudes to health and health care. Over the past 25 years, Maori have become active participants in health policy and health care. Participation in the medical workforce has increased from $0.5 \%$ to around 3\%, and all major district health boards have appointed senior Maori health managers to spearhead Maori engagement with the health system. ${ }^{10}$

While Maori experience is different from the experiences of Australian Aboriginals and Torres Strait Islanders, there are sufficient commonalities to endorse the relevance of three key principles for indigenous health programs in both countries, which I have discussed in detail elsewhere. ${ }^{10}$ The principle of integrated solutions recognises that no single sector, discipline or service has all the answers and that indigenous health strategies must become part of a comprehensive set of actions. A second principle, indigenous pathways, acknowledges the importance of culture, the contemporary circumstances of indigenous peoples, and indigenous leadership. When indigenous peoples are actively involved in the search for solutions, sustainable, meaningful answers will be more likely. A third principle, empowering partnerships, has relevance to the relationship between governments and indigenous peoples, but it also has significant implications for medical practitioners and health professionals. Effective clinicians engage with patients in ways that endorse cultural identity and create spaces for patients to actively contribute to the encounter. An empowering clinical engagement will be one where health literacy, self-management and self-respect are realised, along with gains in health.

These principles should be recognised at all levels of planning and designing health services for indigenous peoples. There is also considerable room for individual health professionals to demonstrate leadership by actively recognising the wider determinants of health and fostering a connected type of leadership. Such leadership should include leaders from other sectors, such as social services and education, as well as indigenous community leaders.

Competing interests: No relevant disclosures.

Provenance: Commissioned; externally peer reviewed.

1 Baker MG, Barnard LT, Kvalsvig A, et al. Increasing incidence of serious infectious diseases and inequalities in New Zealand: a national epidemiological study. Lancet 2012; 379: 1112-1119.

2 Robson B, Harris R, editors. Hauora: Maori standards of health IV. A study of the years 2000-2005. Wellington: Te Ropu Rangahau Hauora a Eru Pomare, University of Otago, 2007. http://www.hauora.maori.nz/hauora/ (accessed May 2012).

3 Thomson N, Macrae A Brankovich J, et al. Overview of Australian Indigenous health status, 2011. Perth: Australian Indigenous Health/nfoNet, 2012. http:// www.healthinfonet.ecu.edu.au/health-facts/overviews (accessed May 2012).

4 Commission on Social Determinants of Health. Closing the gap in a generation: health equity through action on the social determinants of health. Final Report of the Commission on Social Determinants of Health. Geneva: World Health Organization, 2008: 16-21. http://www.who.int/social determinants/ thecommission/finalreport/en/index.html (accessed May 2012).

5 Royal Commission on Social Policy. The April report, vol. 2. Wellington: RCSP, 1988.

6 United Nations declaration on the rights of indigenous peoples (A/RES/61/ 295). New York: UN, 2007. http://social.un.org/index/IndigenousPeoples/ DeclarationontheRightsofIndigenousPeoples.aspx (accessed May 2012).

7 Statistics New Zealand. Births and deaths: March 2009 quarter. Wellington: Statistics NZ, 2009. http://www.stats.govt.nz/browse for_stats/population/ births/BirthsAndDeaths_HOTPMar09qtr.aspx (accessed May 2012).

8 Blakely T, Tobias M, Atkinson J, et al. Tracking disparity: trends in ethnic and socioeconomic inequalities in mortality, 1981-2004. Wellington: Ministry of Health, 2007. http://www.health.govt.nz/publication/tracking-disparitytrends-ethnic-and-socioeconomic-inequalities-mortality-1981-2004 (accessed May 2012).

9 No smoke signals in Turia's vision. Dominion Post (Wellington) 28 Apr 2012: C2.

10 Durie M. Nga Tini Whetu: navigating Maori futures. Wellington: Huia Publishers, 2011: 11-27, 377-378.

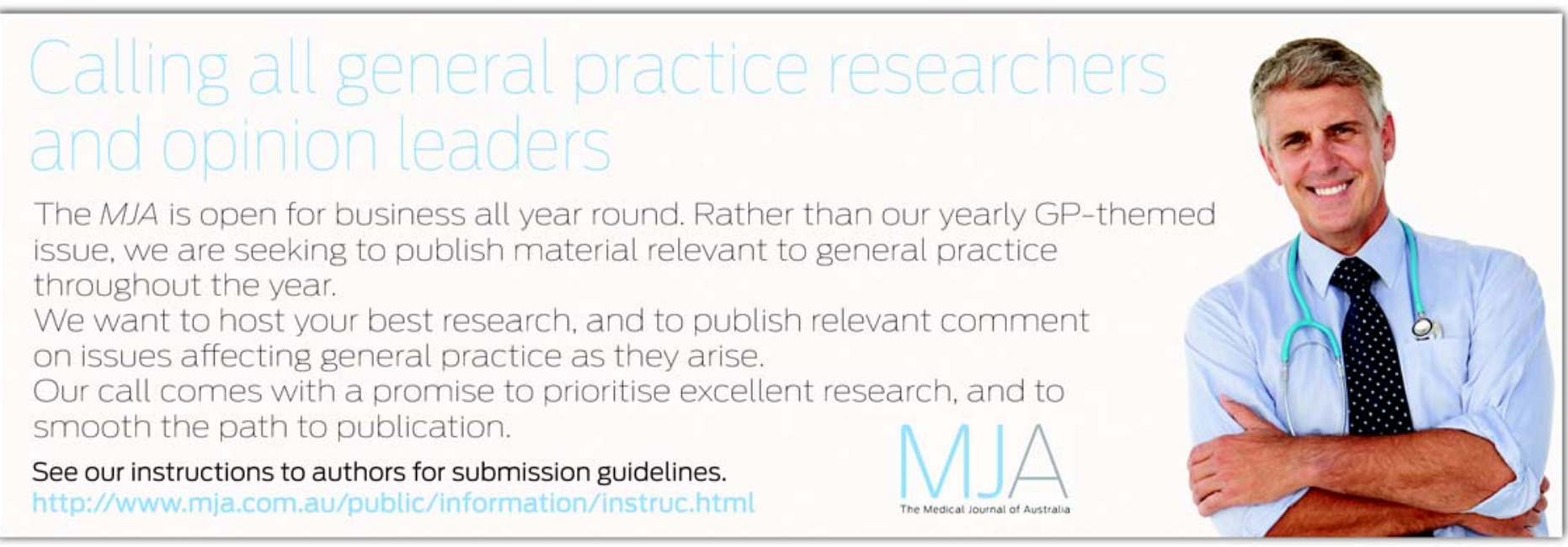

